\title{
Decadal record of satellite carbon monoxide observations
}

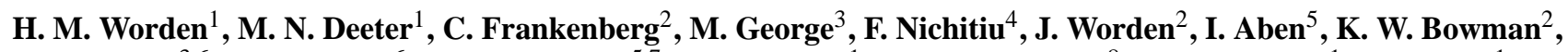 \\ C. Clerbaux ${ }^{3,6}$, P. F. Coheur ${ }^{6}$, A. T. J. de Laat ${ }^{5,7}$, R. Detweiler ${ }^{1}$, J. R. Drummond ${ }^{8}$, D. P. Edwards ${ }^{1}$, J. C. Gille ${ }^{1}$, \\ D. Hurtmans ${ }^{6}$, M. Luo ${ }^{2}$, S. Martínez-Alonso ${ }^{3}$, S. Massie ${ }^{1}$, G. Pfister ${ }^{1}$, and J. X. Warner ${ }^{9}$ \\ ${ }^{1}$ National Center for Atmospheric Research (NCAR), Boulder, CO, USA \\ ${ }^{2}$ Jet Propulsion Laboratory, California Institute of Technology, Pasadena, CA, USA \\ ${ }^{3}$ UPMC Univ. Paris 06; Université Versailles St-Quentin; CNRS/INSU, LATMOS-IPSL, Paris, France \\ ${ }^{4}$ Dept. of Physics and Atmospheric Science, University of Toronto, Toronto, Ontario, Canada \\ ${ }^{5}$ SRON Netherlands Institute for Space Research, Utrecht, The Netherlands \\ ${ }^{6}$ Spectroscopie de l'Atmosphère, Service de Chimie Quantique et Photophysique, Libre Université de Bruxelles (ULB), \\ Brussels, Belgium \\ ${ }^{7}$ Royal Netherlands Meteorological Institute (KNMI), De Bilt, The Netherlands \\ ${ }^{8}$ Dept. of Physics and Atmospheric Science, Dalhousie University, Halifax, Nova Scotia, Canada \\ ${ }^{9}$ Dept. of Atmospheric and Oceanic Science, Univ. of Maryland, College Park, MD, USA
}

Correspondence to: H. M. Worden (hmw@ucar.edu)

Received: 26 July 2012 - Published in Atmos. Chem. Phys. Discuss.: 28 September 2012

Revised: 20 December 2012 - Accepted: 15 January 2013 - Published: 22 January 2013

\begin{abstract}
Atmospheric carbon monoxide (CO) distributions are controlled by anthropogenic emissions, biomass burning, transport and oxidation by reaction with the hydroxyl radical $(\mathrm{OH})$. Quantifying trends in $\mathrm{CO}$ is therefore important for understanding changes related to all of these contributions. Here we present a comprehensive record of satellite observations from 2000 through 2011 of total column CO using the available measurements from nadir-viewing thermal infrared instruments: MOPITT, AIRS, TES and IASI. We examine trends for $\mathrm{CO}$ in the Northern and Southern Hemispheres along with regional trends for Eastern China, Eastern USA, Europe and India. We find that all the satellite observations are consistent with a modest decreasing trend $\sim-1 \% \mathrm{yr}^{-1}$ in total column $\mathrm{CO}$ over the Northern Hemisphere for this time period and a less significant, but still decreasing trend in the Southern Hemisphere. Although decreasing trends in the United States and Europe have been observed from surface $\mathrm{CO}$ measurements, we also find a decrease in $\mathrm{CO}$ over E. China that, to our knowledge, has not been reported previously. Some of the interannual variability in the observations can be explained by global fire emissions, but the overall decrease needs further study to understand the implications for changes in anthropogenic emissions.
\end{abstract}

\section{Introduction}

Carbon monoxide (CO) is measured from space by several instruments due to its important role in atmospheric chemistry and climate. $\mathrm{CO}$ emissions have an indirect radiative forcing around $0.2 \mathrm{~W} \mathrm{~m}^{-2}$ (Forster et al., 2007, IPCC AR4) since $\mathrm{CO}$ is a chemical precursor of greenhouse gases $\mathrm{CO}_{2}$ and tropospheric $\mathrm{O}_{3}$. The sources of $\mathrm{CO}$ are incomplete combustion processes, including fossil fuel and biofuel burning, wildfires and agricultural biomass burning, as well as secondary chemical production from hydrocarbon oxidation. The primary sink of $\mathrm{CO}$ is oxidation by the hydroxyl radical $(\mathrm{OH})$. Because $\mathrm{CO}$ has a medium lifetime (weeks to months), it can be transported globally, but does not become evenly mixed in the troposphere. This makes $\mathrm{CO}$ an ideal tracer of transport processes from pollution sources which often produce significant enhancements over background values (e.g., Edwards et al., 2004; 2006).

Global direct emissions of $\mathrm{CO}$ are dominated by relatively stable anthropogenic emissions $(\sim 500-600 \mathrm{Tg}$ yr -1$)$ and by biomass burning with significant interannual variability ( 300-600 Tg yr-1), (e.g., Granier et al., 2011, van der Werf et al., 2010). Satellite observations of CO can clearly identify areas of intense burning (e.g., Edwards et al., 2006; 
Turquety et al., 2009), as well as urban areas (Clerbaux et al., 2008a). However, due to large chemical sources and sinks and large scale transport, $\mathrm{CO}$ concentrations in the atmosphere are not only driven by direct emissions. A full understanding of the emissions, chemistry and transport is required to model $\mathrm{CO}$ in the atmosphere, or conversely, to use $\mathrm{CO}$ measurements in an inversion for $\mathrm{CO}$ emissions, as shown by e.g., Arellano et al., 2004, Jones et al., 2009, Kopacz et al., 2010 and Fortems-Cheiney et al., 2011.

This study presents a compilation of the available longterm satellite measurements of total column CO from 2000 through 2011. While limb-viewing instruments such as AuraMLS (Microwave Limb Sounder) (Livesey et al., 2008) and ACE-FTS (Atmospheric Chemistry Experiment-Fourier Transform Spectrometer) (Clerbaux et al., 2008b) also measure $\mathrm{CO}$ abundance in the upper troposphere and stratosphere, they do not sample enough of the middle and lower troposphere to provide $\mathrm{CO}$ total columns. Here we use $\mathrm{CO}$ total columns derived from thermal-infrared (TIR) observations using $\mathrm{CO}$ absorption lines around $4.6 \mu \mathrm{m}$ from TerraMOPITT (Measurements of Pollution in the Troposphere), Aqua-AIRS (Atmospheric InfraRed Sounder), Aura-TES (Tropospheric Emission Spectrometer) and MetOp-IASI (Infrared Atmospheric Sounding Interferometer).

We also examined Envisat-SCIAMACHY (SCanning Imaging Absorption spectroMeter for Atmospheric CHartographY) total column CO products (de Laat et al., 2006), which use near-infrared (NIR) observations of reflected sunlight over land and ocean scenes with low clouds (Gloudemans et al., 2009 and references therein). However, time dependent differences in sampling and instrument instabilities in the $2.3 \mu \mathrm{m}$ channel currently hamper their use in trend detection at the $1 \% \mathrm{yr}^{-1}$ level that is observed by the TIR instruments. Consequently, no obvious trend (increasing or decreasing) was observed in the 6-yr (2003-2008) SCIAMACHY data record of total column $\mathrm{CO}$ over any of the regions.

TIR measurements generally have good sensitivity to $\mathrm{CO}$ in the middle troposphere, broadly peaking around $500 \mathrm{hPa}$ (Deeter et al., 2004; Luo et al., 2007b; Warner et al., 2007; George et al., 2009), with sensitivity into the lower troposphere when there is sufficient thermal contrast, i.e., the difference in temperature between the surface and lower troposphere. Since thermal contrast is generally better for daytime observations and over land (e.g., Deeter et al., 2007; Clerbaux et al., 2009), we restrict this study to daytime observations only. Correlations, biases and measurement differences for the nadir viewing TIR instruments are provided in George et al. (2009). As of this study, MOPITT, AIRS and IASI are performing nominal operations. TES is still operating, but with reduced sampling (both spatial and temporal) after 2010.

This paper is organized as follows: in Sect. 2 we describe the instruments that make nadir observations of $\mathrm{CO}$. In Sect. 3 we show the time series and trends derived from these observations. In Sect. 4 we discuss the significance of the trends and we give our conclusions in Sect. 5.

\section{Observations}

\subsection{MOPITT}

MOPITT instrument is a multi-channel TIR and NIR instrument on board the EOS-Terra satellite launched in 1999 into a sun-synchronous polar orbit with $\sim 10: 30$ am local time descending node equator crossing. MOPITT has horizontal spatial resolution around $22 \mathrm{~km} \times 22 \mathrm{~km}$ and a swath width around $640 \mathrm{~km}$, which allows global coverage every 3 days. MOPITT uses gas-cell correlation radiometry (Tolton and Drummond, 1997; Edwards et al., 1999; Drummond et al., 2010) to detect atmospheric CO absorption at $4.6 \mu \mathrm{m}$ (TIR channels) and $2.3 \mu \mathrm{m}$ (NIR channels). $\mathrm{CO}$ in the MOPITT gas cells forms an optical filter at the CO spectral line positions so that observed TOA (top-of-atmosphere) radiances are filtered to produce an optical signal specific to $\mathrm{CO}$ as measured by the detectors. By modulating gas cell pressure or path length, the widths of $\mathrm{CO}$ absorption lines are varied and information on atmospheric $\mathrm{CO}$ distributions can be obtained from the radiance differences and averages taken at the modulation maxima and minima. For the TIR channels, differences in the radiance measurements provide sensitivity to the pressure broadened absorption of $\mathrm{CO}$ at different altitudes in the atmosphere while radiance averages give information on surface temperature and emissivity. MOPITT retrievals of the $\mathrm{CO}$ volume mixing ratio profile use optimal estimation (Deeter et al., 2011 and references therein) and a retrieval grid with ten levels. The total column $\mathrm{CO}$ product is not directly retrieved, but rather is based on the integral of the retrieved $\mathrm{CO}$ volume mixing ratio profile. Above $50 \mathrm{hPa}$, the shape of the mixing ratio profile is derived from the MOZART climatology, which also serves as the basis of the MOPITT a priori profiles (Deeter et al., 2010). This climatology used MOZART-4 simulations (Emmons et al., 2010) with 28 vertical levels from the surface to $2 \mathrm{hPa}$ and $2.8 \times 2.8$ deg horizontal resolution. The contribution of stratospheric $\mathrm{CO}$ from pressures below $100 \mathrm{hPa}$ to the total column is typically less than $5 \%$ for mid-latitudes and less than $9 \%$ for the tropics. The MOZART climatology has monthly, but not interannual variability, hence it is not a source of any decadal trends observed in the MOPITT data.

In this study we use MOPITT V5 data (Worden et al., 2010; Deeter et al., 2011; Deeter et al., 2012). In order to compare with the other TIR instruments (AIRS, TES and IASI), we use the retrievals of $\mathrm{CO}$ from the TIR channels only (V5T data). The retrievals from the NIR channel are only possible over land for MOPITT. CO total columns from the MOPITT multispectral retrievals combining TIR and NIR channels are very similar to the TIR-only results, but are not directly comparable to any of the other instruments. 
Table 1. NOAA Validation Sites for in-situ CO profiles*.

\begin{tabular}{llll}
\hline NOAA Validation Site & Latitude & Longitude & Observational Period \\
\hline Briggsdale, Colorado & $40.37^{\circ} \mathrm{N}$ & $104.3^{\circ} \mathrm{W}$ & $13 / 01 / 00-30 / 08 / 11$ \\
Molokai, Hawaii & $21.23^{\circ} \mathrm{N}$ & $158.95^{\circ} \mathrm{W}$ & $31 / 01 / 00-22 / 04 / 08$ \\
Poker Flat, Alaska & $65.07^{\circ} \mathrm{N}$ & $147.29^{\circ} \mathrm{W}$ & $07 / 02 / 00-26 / 08 / 11$ \\
Harvard Forest, Massachusetts & $42.54^{\circ} \mathrm{N}$ & $72.17^{\circ} \mathrm{W}$ & $08 / 02 / 00-18 / 11 / 07$ \\
Rarotonga & $21.25^{\circ} \mathrm{S}$ & $159.83^{\circ} \mathrm{W}$ & $17 / 04 / 00-25 / 06 / 11$ \\
Charleston, South Carolina & $32.77^{\circ} \mathrm{N}$ & $79.55^{\circ} \mathrm{W}$ & $22 / 08 / 03-28 / 09 / 09$ \\
Norfolk, Virginia & $36.70^{\circ} \mathrm{N}$ & $75.50^{\circ} \mathrm{W}$ & $28 / 07 / 04-29 / 04 / 07$ \\
Worcester, Massachusetts & $42.95^{\circ} \mathrm{N}$ & $70.63^{\circ} \mathrm{W}$ & $05 / 01 / 08-18 / 08 / 11$ \\
Sinton, Texas & $27.73^{\circ} \mathrm{N}$ & $96.86^{\circ} \mathrm{W}$ & $08 / 01 / 08-16 / 08 / 11$ \\
Cape May, New Jersey & $38.83^{\circ} \mathrm{N}$ & $74.32^{\circ} \mathrm{W}$ & $10 / 01 / 08-17 / 08 / 11$ \\
Beaver Crossing, Nebraska & $40.80^{\circ} \mathrm{N}$ & $97.18^{\circ} \mathrm{W}$ & $19 / 01 / 08-17 / 04 / 11$ \\
West Branch, Iowa & $41.72^{\circ} \mathrm{N}$ & $91.35^{\circ} \mathrm{W}$ & $19 / 01 / 08-31 / 08 / 11$ \\
East Trout Lake, Saskatchewan & $54.35^{\circ} \mathrm{N}$ & $104.98^{\circ} \mathrm{W}$ & $26 / 01 / 08-19 / 08 / 11$ \\
Dahlen, North Dakota & $47.50^{\circ} \mathrm{N}$ & $99.24^{\circ} \mathrm{W}$ & $11 / 03 / 08-28 / 06 / 11$ \\
Trinidad Head, California & $41.05^{\circ} \mathrm{N}$ & $124.15^{\circ} \mathrm{W}$ & $22 / 03 / 08-08 / 08 / 11$ \\
\hline
\end{tabular}

* more station information listed at http://www.esrl.noaa.gov/gmd/ccgg/aircraft/sites.html.

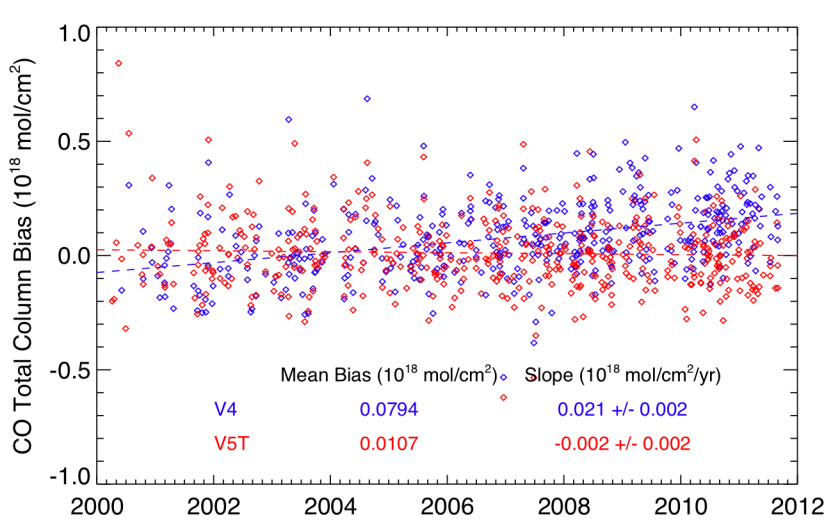

Fig. 1. Time series of MOPITT V4 and V5T retrieval bias for total column $\mathrm{CO}$ determined from validation results using in situ $\mathrm{CO}$ profiles from NOAA sites (listed in text). Retrieval bias statistics (including long-term drift) for individual sites are consistent with the overall statistics, i.e., no clear geographical dependence is observed in the validation results.

MOPITT V3 and V4 CO profiles and columns were validated with respect to NOAA aircraft in situ CO profile measurements (Emmons et al., 2009; Deeter et al., 2010) and we show a similar comparison for the MOPITT V5T total column with respect to validation data in Fig. 1, along with the latest comparison for V4. The NOAA sites used for validation are listed in Table 1. Routine in situ profiles are collected at bi-weekly to monthly frequency, depending on the site, with $\sim 1$ ppb precision for CO (Novelli et al., 1998). MOPITT retrievals taken within 12 hours and $50 \mathrm{~km}$ of the NOAA flights were used for these comparisons. For MOPITT V5T, the total column does not have a significant time dependent bias with respect to in-situ data. For MOPITT V4, the total column bias with respect to in situ data increased by
$(0.021 \pm 0.002) \times 10^{18} \mathrm{~mol} \mathrm{~cm}^{-2} \mathrm{yr}^{-1}$, or $\sim 1 \% \mathrm{yr}^{-1}$. This was mostly due to the use of static instrument parameters in the V4 forward model. The V5 forward model accounts for the instrument time dependence by including monthly mean values for the cell parameters. The increase in total column $\mathrm{CO}$ due to instrument drift in V4 is enough to obscure the decreasing trend we see in V5 data. Previous studies of global trends using MOPITT V4 data (Yurganov et al., 2010 and Fortems-Cheiney et al., 2011) show some of the same features as seen here with MOPITT V5, especially after applying a correction to agree with surface validation sites in Yurganov et al. (2010). However, with the explicit correction for instrument cell parameter drift in MOPITT V5, we now see better agreement with the other satellite observations and in-situ measurements.

\subsection{AIRS}

AIRS is a TIR grating spectrometer on board EOS-Aqua launched in 2002 into a sun-synchronous polar orbit with $\sim 13: 15$ local time for the ascending node equator crossing (Aumman et al., 2003). AIRS has $13.5 \mathrm{~km} \times 13.5 \mathrm{~km}$ horizontal spatial resolution, however, the AIRS algorithm utilizes cloud-clearing processes (Susskind et al., 2003) that increase the global coverage significantly, but reduce the spatial resolution to $45 \mathrm{~km} \times 45 \mathrm{~km}$. AIRS has a $1650 \mathrm{~km}$ swath providing near global coverage twice daily. AIRS resolving power is $\lambda / \Delta \lambda=1200$, resulting in a spectral resolution $\sim 1.8 \mathrm{~cm}^{-1}$ for the $4.6 \mu \mathrm{m} \mathrm{CO}$ absorption. AIRS radiance spectra are used to determine cloud and surface properties along with vertical profiles of atmospheric trace gases and temperature. AIRS CO retrievals have been compared to MOPITT and in situ data (Warner et al., 2007), which showed good agreement in AIRS-MOPITT horizontal spatial 


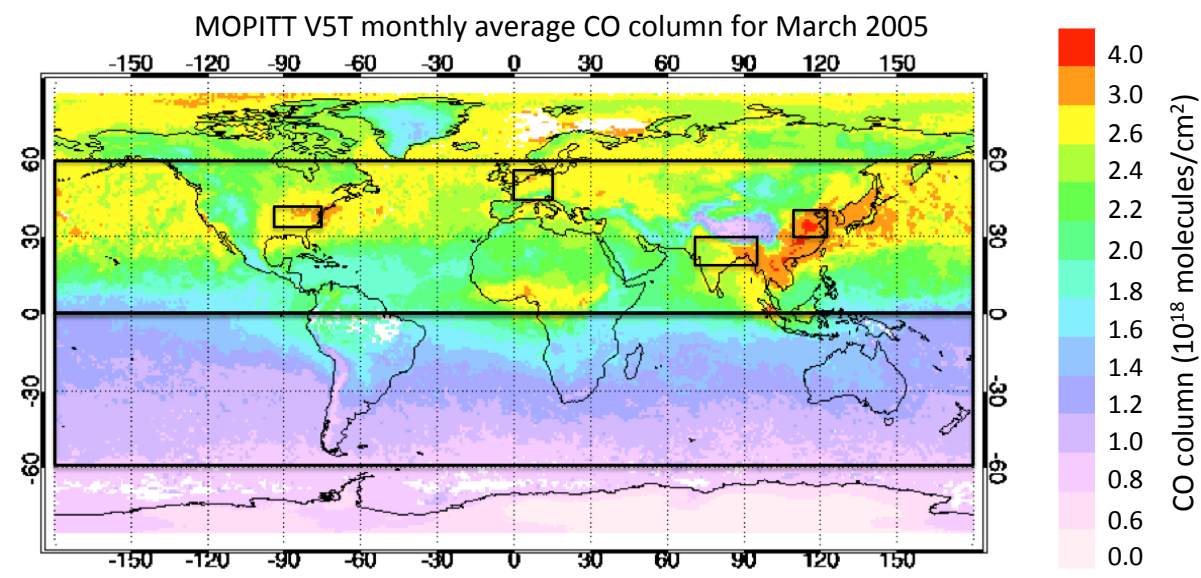

Fig. 2. Global map showing MOPITT V5T monthly average CO column for March 2005 indicating the regions used for estimating trends in this study: Northern Hemisphere $\left[0^{\circ}-60^{\circ} \mathrm{N}\right]$, Southern Hemisphere $\left[0^{\circ}-60^{\circ} \mathrm{S}\right]$, E. USA $\left[35^{\circ}-40^{\circ} \mathrm{N},-95^{\circ}\right.$ to $-75^{\circ}$ E], Europe $\left[45^{\circ}-55^{\circ} \mathrm{N}\right.$, $\left.0^{\circ}-15^{\circ} \mathrm{E}\right]$, India $\left[20^{\circ}-30^{\circ} \mathrm{N}, 70^{\circ}-95^{\circ} \mathrm{E}\right]$ and E. China $\left[30^{\circ}-40^{\circ} \mathrm{N}, 110^{\circ}-123^{\circ} \mathrm{E}\right]$.

variability. This comparison found AIRS CO higher than MOPITT (V3) by $15-20 \mathrm{ppb}$ at $500 \mathrm{hPA}$ over ocean observations, however, Warner et al. (2007) used older versions of both AIRS and MOPITT data than the comparisons presented here.

\subsection{TES}

TES is a TIR Fourier Transform Spectrometer (FTS) onboard the NASA EOS-Aura platform launched in 2004 into sun-synchronous orbit with $\sim 13: 40$ ascending node equator crossing time. Aura follows Aqua in the so-called "A-Train" orbit, so that TES nadir observations are around $25 \mathrm{~min}$ later than AIRS. TES measures radiance spectra at frequencies between $650-2250 \mathrm{~cm}^{-1}$ of the earth's surface and atmosphere, with relatively fine spectral resolution $\left(0.10 \mathrm{~cm}^{-1}\right.$, apodized) (Beer, 2006). These spectra are used to derive vertical profiles of atmospheric temperature and trace gases, along with effective cloud pressure and optical depth, surface temperature and land emissivity. TES CO profiles and total column amounts have been validated with respect to in situ measurements (Luo et al., 2007a) and compared to MOPITT V3 data (Luo et al., 2007b) and to MOPITT data processed with the TES a priori profiles and covariances (Ho et al., 2009). When a priori profiles and covariances are the same for both TES and MOPITT retrievals, column differences are less than $6.5 \%$ globally, with MOPITT higher than TES. Unlike MOPITT, AIRS and IASI, TES has relatively sparse sampling, only along the orbit track. However, sampling was sufficient for comparisons of monthly averages in the regions chosen for trend analysis.

\subsection{IASI}

IASI is a TIR-FTS launched in October 2006 on the polar orbiting MetOp-A satellite, with a 9:30 a.m. local time equa- tor crossing for the descending node. IASI has 4 pixels with $12 \mathrm{~km}$ diameter (at nadir) and a $2200 \mathrm{~km}$ swath which provide global coverage twice daily. IASI spectral resolution is $0.5 \mathrm{~cm}^{-1}$ (apodized) with continuous spectral coverage from 645 to $2760 \mathrm{~cm}^{-1}$ that allows column and profile retrievals of several different trace gases (Clerbaux et al., 2009). Up to now, 24 different gases have been monitored, or detected in special events such as pollution, fire or volcanic plumes (Clarisse et al., 2011). For carbon monoxide, profiles are retrieved using an optimal estimation approach, implemented in the Fast Optimal Retrievals on Layers for IASI (FORLI) software (Hurtmans et al., 2012). The spectra are processed in near real time and the $\mathrm{CO}$ profiles are distributed with error covariance, averaging kernels and quality flags information (see http://ether.ipsl.jussieu.fr). The IASI CO product was validated against ground based observations (Kerzenmacher et al., 2012), aircraft data (Pommier et al., 2010, Klonecki et al., 2012) and satellite measurements (George et al., 2009).

\section{Trend estimation}

\subsection{Data selection}

Figure 2 shows a global map of monthly averaged MOPITT total column CO for March, 2004 indicating the regions considered for trend estimates in this paper.

These regions were chosen to provide trends over highly populated regions in contrast to the hemispherical trends. Table 2 gives a summary of the data versions and filtering applied for each instrument and Table 3 gives the average number of observations per month $(\mathrm{N} / \mathrm{mo})$ and $\mathrm{CO}$ total column standard deviation for the latitude/longitude ranges used in this study. The values for $\mathrm{N} / \mathrm{mo}$ and standard deviation vary significantly across the instruments due to the type of data used (gridded L3 averages vs. single L2 observations), 
Table 2. Data selection information by instrument. Single observation uncertainty is the average retrieval error for individual total column $\mathrm{CO}$ estimates.

\begin{tabular}{|c|c|c|c|c|}
\hline & MOPITT & AIRS & TES & IASI \\
\hline Instrument type & Gas correlation radiometer & Grating spectrometer & FTS & FTS \\
\hline Data version & $\begin{array}{l}\text { V5T } \\
\text { (TIR-only) }\end{array}$ & $\begin{array}{l}\text { V5 } \\
\text { (L3 gridded) }\end{array}$ & V4 & $\begin{array}{l}\text { FORLI } \\
\text { v20100815 }\end{array}$ \\
\hline Cloud removal method & $\begin{array}{l}\text { Cloud-free } \\
<5 \% \text { in pixel }\end{array}$ & $\begin{array}{l}\text { Cloud-cleared } \\
\text { radiances }\end{array}$ & $\begin{array}{l}\text { Eff. OD* } \\
<0.4\end{array}$ & $\begin{array}{l}\text { Cloud-free } \\
<25 \% \text { in pixel }\end{array}$ \\
\hline $\begin{array}{l}\text { Data quality } \\
\text { filters }\end{array}$ & DFS $^{*}>0.75$ & $\mathrm{QA}^{*}=0$ or 1 & $\begin{array}{l}\mathrm{QF}^{*}=1 \\
\mathrm{DFS}>0.9\end{array}$ & $\begin{array}{l}\text { bias* } \\
\text { RMS* }\end{array}$ \\
\hline Single obs. uncertainty & $5-6 \%$ & $10 \%$ & $6-7 \%$ & $5-7 \%$ \\
\hline Data set time range & 03/2000-05/2012 & 09/2002-05/2012 & $01 / 2005-12 / 2010$ & 01/2008-05/2012 \\
\hline Instr. operation & $4-7 / 2001$ & none & $4-6 / 2005$ & none \\
\hline gaps & $8-9 / 2009$ & & $1-3 / 2010$ & \\
\hline
\end{tabular}

* Terminology: Eff. OD = effective cloud optical depth; DFS = degrees of freedom for signal; QA = Quality Assurance (see text for value definition); QF $=$ quality flag; RMS $=$ root-mean-square. For IASI data, bias and RMS are in $\mathrm{W} /\left(\mathrm{cm}^{2} \mathrm{srcm}^{-1}\right)$ with ranges:

$-0.15 \times 10^{-9}<=$ bias $<=0.25 \times 10^{-9}$ and RMS $<=2.7 \times 10^{-9}$.

different instrument sampling and retrieval algorithms. For example, the standard deviations for IASI are higher likely due to more sampling of anomalous events as well as differences in the apriori constraints applied in the retrieval.

\subsubsection{MOPITT data}

MOPITT retrievals are performed for cloud free scenes using a cloud mask determined by data from Terra-MODIS (Ackerman et al., 1998) and MOPITT (Warner et al., 2001).

For the Northern and Southern Hemisphere (NH and $\mathrm{SH}$ ) monthly averages, we use MOPITT level 3 (L3) monthly averages with latitudes 0 to $60^{\circ}$, all longitudes, daytime only. MOPITT L3 data are weighted by an observation quality index (OQI) before averaging. The OQI is defined in the MOPITT V5 Users Guide, March 2011, available at http://www.acd.ucar.edu/mopitt/publications.shtml. Weighting by the OQI gives more weight to observations with less geophysical noise (Deeter et al., 2011). In order to reject retrievals that have a significant influence from the apriori profile while maintaining relatively uniform sampling across latitudes, we selected data with degrees of freedom for signal (DFS) $>0.75$. For the regional averages, we use MOPITT L2 data, also weighted by the OQI and we selected daytime, land-only scenes with DFS $>1.0$. MOPITT L2 data were used so that we could apply a correction for geolocation errors in MOPITT data processing (see the Geolocation Bias Report, 2012, also at http://www.acd.ucar. edu/mopitt/publications.shtml.) To account for this error, we added $0.35^{\circ}$ to the longitude values before selecting and averaging over the latitude and longitude ranges used for this study.

\subsubsection{AIRS data}

For this study we use AIRS V5 L3 monthly mean products from the Giovanni application provided by GES-DISC (Goddard Earth Sciences Data and Information Center). Giovanni allows selection of AIRS total column CO for user-selected geographic areas and time ranges. Monthly average L3 data are gridded by $1^{\circ} \times 1^{\circ}$ (latitude $\times$ longitude) and filtered by Quality Assurance (QA) as good ( $\mathrm{QA}=0$ or 1$)$, where values of 0,1 and 2 indicate "best", "good" and "do not use", respectively. AIRS V5 L3 monthly data were selected for daytime (ascending orbits) and averaged for the latitude and longitude ranges used in this study without further weighting or filtering.

\subsubsection{TES data}

The TES L2 algorithm performs retrievals on both clear and cloudy scenes and cloudy scenes were removed before computing the monthly averages used in this study. TES V4 L2 data were selected for daytime retrievals with quality flag $=1$ (good) and DFS $>0.9$. Criteria for cloud-free data are an effective cloud optical depth (OD) $<0.4$ and land-only data were used in the regional averages. Note that starting in 2010, routine sampling of the $\mathrm{SH}$ was limited to northward of $30^{\circ} \mathrm{S}$ in order to conserve instrument lifetime. Therefore, TES data are not included for the SH after 2009.

\subsubsection{IASI data}

The IASI column values used here are daytime data that were processed with version 20100815 of the FORLI-CO retrieval algorithm. All data corresponding to a cloud fraction flag between 0 and $25 \%$ were further analyzed (Clerbaux et al., 2009). Standard filtering as recommended in Hurtmans et al. (2012) was applied to residual radiances (in 
Table 3. Averages for number of observations per month and CO column standard deviation by instrument. N/mo is the average number of observations per month and $\sigma$ is the CO total column standard deviation (in $10^{18}$ molecules $\mathrm{cm}^{-2}$ ). For AIRS L3 data, we show a representative month (4/2006), with $\mathrm{N} / \mathrm{mo}$ as the number of $1^{\circ} \times 1^{\circ}$ bins in each latitude/longitude range.

\begin{tabular}{|c|c|c|c|c|c|}
\hline & & MOPITT & AIRS & TES & IASI \\
\hline $\begin{array}{l}\mathrm{NH} \\
0-60^{\circ} \mathrm{N}\end{array}$ & $\mathrm{N} / \mathrm{mo}$ & $\begin{array}{l}\text { (L2) } 1.091 \times 10^{6} \\
\text { (L3) } 19558\end{array}$ & 21569 & 8220 & $2.021 \times 10^{6}$ \\
\hline & $\sigma$ & 0.37 & 0.27 & 0.37 & 0.44 \\
\hline $\begin{array}{l}\mathrm{SH} \\
0-60^{\circ} \mathrm{S}\end{array}$ & $\mathrm{N} / \mathrm{mo}$ & $\begin{array}{l}\text { (L2) } 877203 \\
\text { (L3) } 19480\end{array}$ & 21599 & 6161 & $1.924 \times 10^{6}$ \\
\hline & $\sigma$ & 0.28 & 0.16 & 0.34 & 0.40 \\
\hline E. China ${ }^{1}$ & $\begin{array}{l}\mathrm{N} / \mathrm{mo} \\
\sigma\end{array}$ & $\begin{array}{l}3222 \\
0.49\end{array}$ & $\begin{array}{l}130 \\
0.29\end{array}$ & $\begin{array}{l}86 \\
0.69\end{array}$ & $\begin{array}{l}10658 \\
0.97\end{array}$ \\
\hline E. USA ${ }^{2}$ & $\begin{array}{l}\mathrm{N} / \mathrm{mo} \\
\sigma\end{array}$ & $\begin{array}{l}3276 \\
0.16\end{array}$ & $\begin{array}{l}100 \\
0.08\end{array}$ & $\begin{array}{l}76 \\
0.23\end{array}$ & $\begin{array}{l}8827 \\
0.30\end{array}$ \\
\hline Europe $^{3}$ & $\begin{array}{l}\mathrm{N} / \mathrm{mo} \\
\sigma\end{array}$ & $\begin{array}{l}1823 \\
0.16\end{array}$ & $\begin{array}{l}149 \\
0.14\end{array}$ & $\begin{array}{l}43 \\
0.30\end{array}$ & $\begin{array}{l}6184 \\
0.30\end{array}$ \\
\hline India $^{4}$ & $\begin{array}{l}\mathrm{N} / \mathrm{mo} \\
\sigma\end{array}$ & $\begin{array}{l}12003 \\
0.27\end{array}$ & $\begin{array}{l}250 \\
0.40\end{array}$ & $\begin{array}{l}63 \\
0.33\end{array}$ & $\begin{array}{l}20062 \\
0.54\end{array}$ \\
\hline
\end{tabular}

${ }^{1}$ E. China $\left[30^{\circ}-40^{\circ} \mathrm{N}, 110^{\circ}-123^{\circ} \mathrm{E}\right]$

2 E. USA $\left[35^{\circ}-40^{\circ} \mathrm{N},-95^{\circ}\right.$ to $\left.-75^{\circ} \mathrm{E}\right]$

${ }^{3}$ Europe $\left[45^{\circ}-55^{\circ} \mathrm{N}, 0^{\circ}-15^{\circ} \mathrm{E}\right]$

${ }^{4}$ India $\left[20^{\circ}-30^{\circ} \mathrm{N}, 70^{\circ}-95^{\circ} \mathrm{E}\right]$.

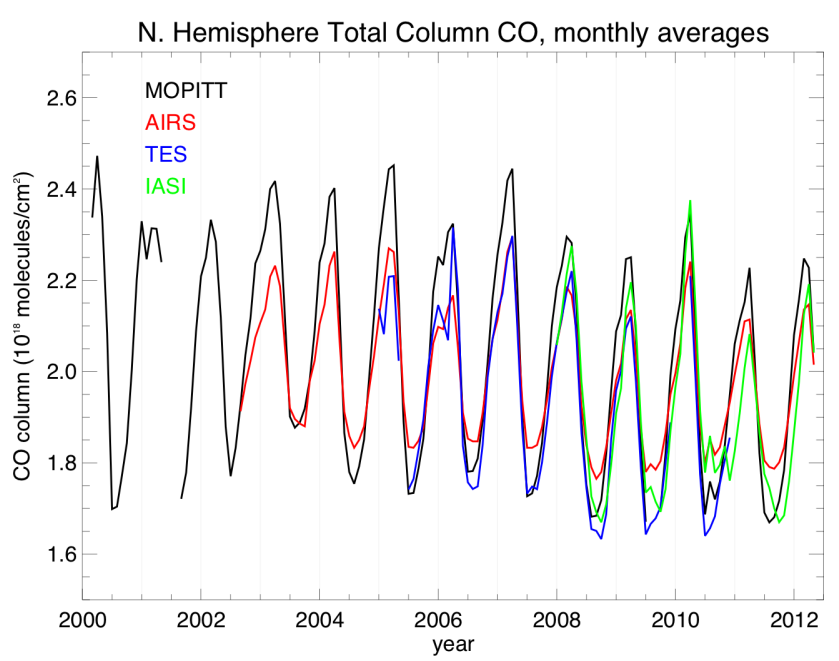

Fig. 3. Time series of $\mathrm{N}$. Hemisphere $\left(0^{\circ}-60^{\circ} \mathrm{N}\right)$ monthly averages.

$\left.\mathrm{W}\left(\mathrm{cm}^{-2} \mathrm{sr} \mathrm{cm}^{-1}\right)\right):-0.15 \times 10^{-9}<=$ bias $<=0.25 \times 10^{-9}$ and RMS $<=2.7 \times 10^{-9}$.

\subsection{Monthly mean time series and instrument biases}

The seasonal behavior of background levels of $\mathrm{CO}$ in the atmosphere is dominated by the changes in incoming solar radiation, thus $\mathrm{OH}$ radical concentrations. Reactions with $\mathrm{OH}$ determine the CO lifetime, which varies from a few weeks in summer to several months in winter at mid-latitudes (e.g., Holloway et al., 2000). Build-up of CO over the winter produces a $\mathrm{CO}$ maximum in late winter to early spring, after

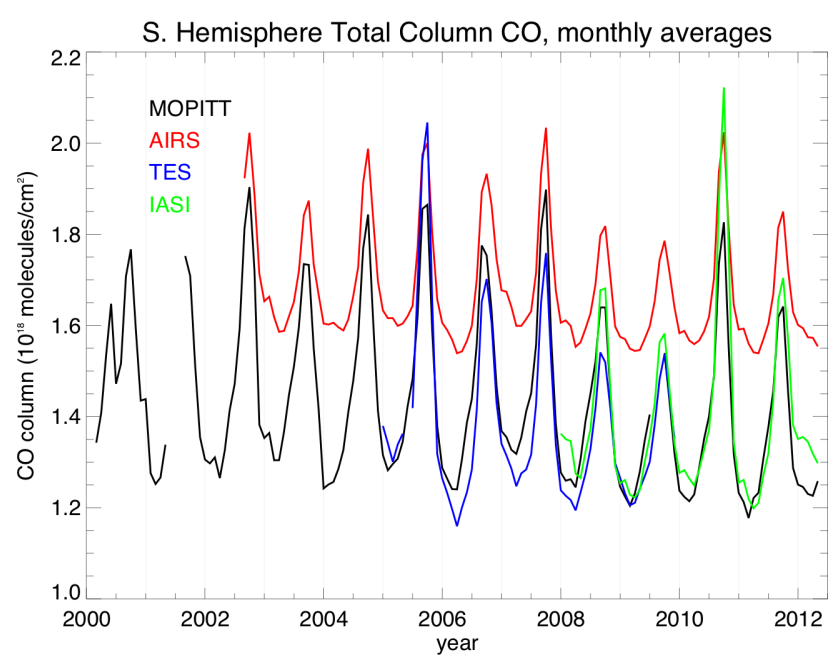

Fig. 4. Time series of S. Hemisphere $\left(0^{\circ}-60^{\circ} \mathrm{S}\right)$ monthly averages.

which chemical destruction results in a minimum for late summer to early fall. For the $\mathrm{SH}$, the maximum due to $\mathrm{CO}$ lifetime corresponds to September/October, which is also around the peak in biomass burning for South America and Africa (south of the equator). This results in sharper peaks for the $\mathrm{SH}$ compared to $\mathrm{NH}$, where sources of $\mathrm{CO}$ are more spread out over the year.

Figure 3 shows the monthly mean time series for the $\mathrm{NH}$ $\left(0-60^{\circ} \mathrm{N}\right)$ for all the instrument data records available for March 2000 to May 2012. Figure 4 shows the SH $\left(0-60^{\circ} \mathrm{S}\right)$ monthly mean time series. All instruments show reasonable 
consistency in column amounts and seasonal patterns. The AIRS data show a clear high bias with respect to the other instruments in the SH and a smaller seasonal amplitude in the NH. These biases with MOPITT, TES and IASI have been documented previously by George et al. (2009) and Warner et al. (2010), and are due to differences in instrument spectral resolution and retrieval methods. In particular, the high bias in SH AIRS V5 data is most likely due to the use of a single global first guess profile (Warner et al., 2010). The use of a single global a priori profile was the source of the high bias in SH MOPITT V3 data, which was removed in MOPITT V4 and V5 by the use of the MOZART climatology for a priori profiles (Deeter et al, 2010). However, AIRS seasonal patterns are consistent with the other instruments and here we are comparing the relative time dependence, which should be less influenced by overall measurement bias.

In this study, we have not made any corrections to account for differences in horizontal spatial sampling or vertical sensitivity. Except for the expected bias with AIRS, the remaining spread in $\mathrm{CO}$ column values across the instruments is largely due to spatial sampling differences. In the case of TES, the number of observations is 2 orders of magnitude lower than the other instruments, and varied for different years. Therefore, we would not expect perfect agreement for an average of TES observations that are not co-located with the other instruments. In the $\mathrm{SH}, \mathrm{CO}$ distributions are more driven by biomass burning and observations of any one transient fire event could vary significantly for the different instrument sampling regimes. This is apparent in the IASI data for October, 2010 when IASI sampled intense burning in southern Africa about twice as frequently than MOPITT. Total column results are less sensitive than profile retrievals to differences in vertical sensitivity that are due to instrument parameters, such as spectral resolution, and the choice of constraints in the retrieval algorithms. However there are differences in the instrument column averaging kernels, as shown in George et al. (2009), that would give slightly different results if applied to the same atmospheric distribution.

\subsection{Trend calculation}

\subsubsection{2-month running averages}

Since we are interested in decadal scale trends, we first remove the seasonal variations in $\mathrm{CO}$ using a 12-month running average. Various options are available for truncating the end-points, but here we simply do not use the first and last 6 months for any of the running average plots or trend calculations since these could introduce a dependence on the smoothing method or at worst, spurious results. To produce a running average that properly removes the seasonal cycles, we found that it was necessary to first perform a cubic spline interpolation over gaps in the monthly averages due to halted instrument operations (shown in Table 2).

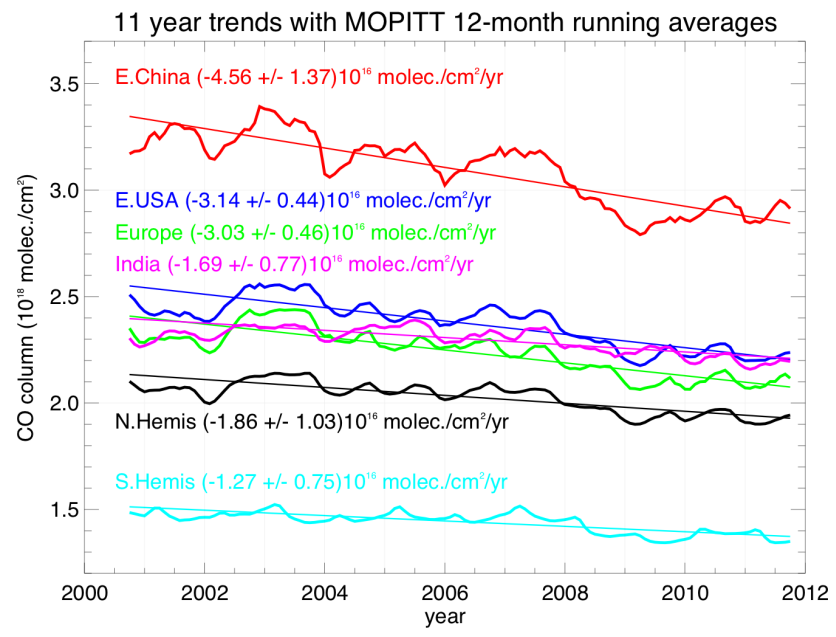

Fig. 5. MOPITT 11-yr regional trends in total $\mathrm{CO}$ column change per year. Regional time series with 12-month running average and corresponding linear trends are indicated by the different colors, with slope and $1 \sigma$ error given in molecules $/ \mathrm{cm}^{2} \mathrm{yr}^{-1}$.

\subsubsection{Linear trend analysis}

To compute linear trends we apply a linear least squares fit to the 12-month running averages, weighted by the standard deviation of the measurements used in the monthly average. For the datasets with months where there were gaps in the data, we use the data record mean standard deviation for each region scaled by a factor of 100 so that these months are deweighted in the fit. We report $1 \sigma$ errors from the linear fits. Figure 5 shows the 12-month running averages and linear fits for 11-yr trends with MOPITT CO total column data for all the spatial regions considered. Table 4 lists slope values, in $\% \mathrm{yr}^{-1}$, for the time periods covered by each of the instruments (where we have cut out at least 6 months at the beginning and end, to account for edge truncation in the 12month running average and to avoid fractional years, if possible). This is a very simplified approach to finding trends, and we will explore the variation in trends computed by different methods (such as different data filtering, different smoothing and empirical orthogonal functions (EOF) analysis) in future analyses. However, for this study, we wanted to show the comparison of all the data records using very basic methods.

For comparisons of relative interannual changes in all the instruments, we normalize each of the 12-month running average time series by the average CO column for a common year, $8 / 2008$ to $7 / 2009$. This removes some of the effects of bias between the instruments and allows a simple assessment of fractional changes over any time period. Figures 6 and 7 show MOPITT, AIRS, TES and IASI 12-month running average time series normalized by $8 / 2008-7 / 2009$ average CO columns for the $\mathrm{NH}$ and $\mathrm{SH}$, respectively, along with linear trends over the MOPITT and AIRS data records. Figure 8 
Table 4. Linear slope $\left(\% \mathrm{yr}^{-1}\right)$ by instrument for available data records. Errors are $1 \sigma$; average CO columns for each time period are in $10^{18}$ molecules $\mathrm{cm}^{-2}$.

\begin{tabular}{|c|c|c|c|c|c|c|}
\hline region & time range & parameters & MOPITT & AIRS & TES & IASI \\
\hline \multirow[t]{4}{*}{ N.H. } & $\begin{array}{l}11 \mathrm{yr} \text { fit } \\
12 / 2000- \\
11 / 2011\end{array}$ & $\begin{array}{l}\text { Slope }\left(\% \mathrm{yr}^{-1}\right) \\
<\mathrm{CO} \text { col }>\end{array}$ & $\begin{array}{l}-0.92 \pm 0.51 \\
2.02\end{array}$ & & \multirow{4}{*}{$\begin{array}{l}-1.66 \pm 1.68 \\
1.94\end{array}$} & \\
\hline & $\begin{array}{l}8 \text { yr fit } \\
12 / 2003- \\
11 / 2011\end{array}$ & $\begin{array}{l}\text { Slope }\left(\% \mathrm{yr}^{-1}\right) \\
<\mathrm{CO} \text { col }>\end{array}$ & $\begin{array}{l}-1.23 \pm 0.73 \\
2.00\end{array}$ & $\begin{array}{l}-0.74 \pm 0.62 \\
1.98\end{array}$ & & \\
\hline & $\begin{array}{l}5 \text { yr fit } \\
06 / 2005- \\
05 / 2010\end{array}$ & $\begin{array}{l}\text { Slope }\left(\% \mathrm{yr}^{-1}\right) \\
<\mathrm{CO} \text { col }>\end{array}$ & $\begin{array}{l}-1.82 \pm 1.33 \\
2.00\end{array}$ & $\begin{array}{l}-1.10 \pm 1.22 \\
1.98\end{array}$ & & \\
\hline & $\begin{array}{l}3.4 \text { yr fit } \\
06 / 2008- \\
11 / 2012\end{array}$ & $\begin{array}{l}\text { Slope }\left(\% \mathrm{yr}^{-1}\right) \\
<\mathrm{CO} \mathrm{col}>\end{array}$ & $\begin{array}{l}-0.4 \pm 2.3 \\
1.94\end{array}$ & $\begin{array}{l}-0.1 \pm 2.3 \\
1.94\end{array}$ & & $\begin{array}{l}-0.9 \pm 3.4 \\
1.90\end{array}$ \\
\hline \multirow[t]{4}{*}{ S.H. } & $\begin{array}{l}11 \mathrm{yr} \text { fit } \\
12 / 2000- \\
11 / 2011\end{array}$ & $\begin{array}{l}\text { Slope }\left(\% \mathrm{yr}^{-1}\right) \\
<\mathrm{CO} \text { col }>\end{array}$ & $\begin{array}{l}-0.88 \pm 0.52 \\
1.44\end{array}$ & & \multirow{4}{*}{$\begin{array}{l}-2.4 \pm 2.7 \\
1.38\end{array}$} & \\
\hline & $\begin{array}{l}8 \text { yr fit } \\
12 / 2003- \\
11 / 2011\end{array}$ & $\begin{array}{l}\text { Slope }\left(\% \mathrm{yr}^{-1}\right) \\
<\mathrm{CO} \text { col }>\end{array}$ & $\begin{array}{l}-1.19 \pm 0.85 \\
1.42\end{array}$ & $\begin{array}{l}-0.54 \pm 0.44 \\
1.68\end{array}$ & & \\
\hline & $\begin{array}{l}4 \text { yr fit } \\
06 / 2005- \\
05 / 2009\end{array}$ & $\begin{array}{l}\text { Slope }\left(\% \mathrm{yr}^{-1}\right) \\
<\mathrm{CO} \text { col }>\end{array}$ & $\begin{array}{l}-1.6 \pm 2.2 \\
1.44\end{array}$ & $\begin{array}{l}-1.03 \pm 1.19 \\
1.68\end{array}$ & & \\
\hline & $\begin{array}{l}3.4 \text { yr fit } \\
06 / 2008- \\
11 / 2012\end{array}$ & $\begin{array}{l}\text { Slope }\left(\% \mathrm{yr}^{-1}\right) \\
<\mathrm{CO} \text { col }>\end{array}$ & $\begin{array}{l}0.1 \pm 3.3 \\
1.37\end{array}$ & $\begin{array}{l}0.7 \pm 1.6 \\
1.65\end{array}$ & & $\begin{array}{l}1.7 \pm 4.6 \\
1.40\end{array}$ \\
\hline
\end{tabular}

shows the normalized time series and linear trends for China, E. USA, Europe and India. For the TES data records shown in Fig. 8, there are a limited number of observations over these regions, listed in Table 3, which can result in a sampling bias with respect to the other instruments, especially over regions with large variability in $\mathrm{CO}$, such as China. Over China, this is further exacerbated by a lower than average number of samples per month for 2005-2007 ( 60 observations per month) while 2008-2009 had higher than average sampling ( $\sim 130$ observations per month). For the other regional and hemispherical averages, TES sampling was more uniformly distributed with time.

Table 4 lists the slopes for $\mathrm{NH}$ and $\mathrm{SH}$, in $\% \mathrm{yr}^{-1}$, with $1 \sigma$ error, for the time range of each data record. None of the time ranges show trends that are significant to $>2 \sigma$ for any of the instruments, so the hemispherical trends only provide the indication of an overall decrease. For the regional trends, we find $>2 \sigma$ significance in China $\left(-1.6\right.$ to $\left.-1 \% \mathrm{yr}^{-1}\right)$, E. USA $\left(-1.4\right.$ to $\left.-1 \% \mathrm{yr}^{-1}\right)$ and Europe $\left(-1.4\right.$ to $\left.-1 \% \mathrm{yr}^{-1}\right)$, for the MOPITT 11-yr and AIRS 8-yr records respectively. The TES and IASI data records do not show significant trends over any of the regions, but show overall consistency with the MOPITT and AIRS time dependence and give confidence to the use of the longer MOPITT and AIRS data records for trend determination.

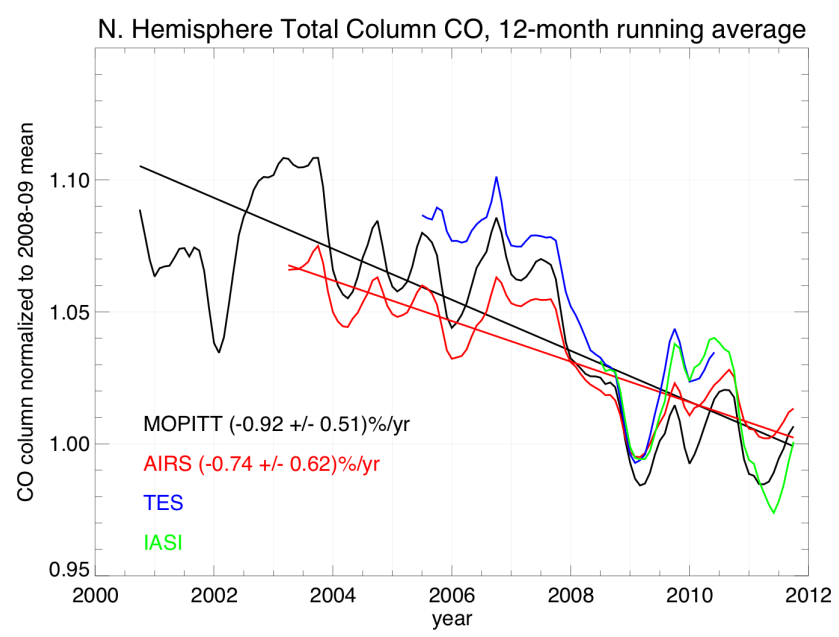

Fig. 6. 12-month running averages for N. Hemisphere total column CO measurements normalized by the $08 / 2008-07 / 2009$ average CO column for each instrument. 
S. Hemisphere Total Column CO, 12-month running average

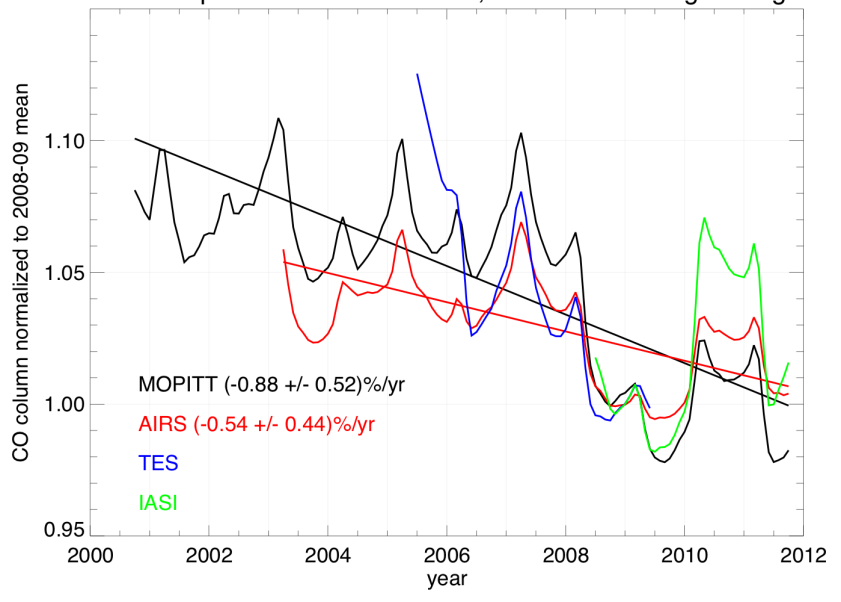

Fig. 7. 12-month running averages for S. Hemisphere total column CO measurements normalized by the $08 / 2008-07 / 2009$ average CO column for each instrument.

\section{Discussion}

\subsection{Interannual variability}

Figures 6-8 demonstrate good agreement in interannual variability for all instruments except in the cases of known sampling issues discussed in Sec. 3. As further verification of the consistency in the MOPITT and AIRS datasets for detecting patterns in interannual variability, Figure 9 shows a zonal average time record of normalized CO total column. 12-month running averages of MOPITT and AIRS CO total columns in $10^{\circ}$ latitude bands are normalized to the time average for each band. The variations in $\mathrm{CO}$ for both instruments are very similar in time and latitude, and both observe a deep minimum in 2009-2010.

In Fig. 10, we show the MOPITT and AIRS 12-month running averages, normalized to the 2008 average column, for a $10^{\circ} \times 10^{\circ}$ spatial average around the NOAA Mauna Loa (MLO) site at $19.5^{\circ} \mathrm{N}$ and $155.6^{\circ} \mathrm{W}$ (Novelli and Masarie, 2010). Due to the high altitude of the site, Mauna Loa measurements are more representative of the free troposphere than other surface measurements and often show the influence of air transported from Asia. Although the in-situ measurements of $\mathrm{CO}$ vmr are not directly comparable to total column CO, and have significantly more interannual variability, MOPITT and AIRS observe many of the same features seen in the MLO in-situ data time series.

All of the 12 month running average time series of total column CO show clear features due to changes in fire emissions such as the broad peak around 2002-2003 for $\mathrm{NH}$ observations due to a significant number of boreal fires (e.g., Yurganov et al., 2005) and an overall decline in global fire emissions from 2007 to 2009 as shown in the GFED3 inventory (van der Werf et al., 2010). There may also be some correlation of lower $\mathrm{CO}$ column to lower emissions due to the global financial crisis starting in late 2008. The observed minimum in CO in early 2009 overlaps with the recorded dip in manufacturing (Alcorta and Nixson, 2011) along with related transportation and shipping decreases (de Ruyter de Wildt et al., 2012). Declines due to the economic crisis are clearly observed for $\mathrm{NO}_{2}$ in Europe (Castellanos and Boersma, 2012) and the US (Russell et al., 2012), however, given the longer lifetime of $\mathrm{CO}$, this would require further study (inverse modeling) for attribution.

\subsection{Trend evaluation}

Only the longer satellite data records $(8-11 \mathrm{yr})$ have trends that are significant above $1 \sigma$. This underscores the importance of maintaining consistent long-term $\mathrm{CO}$ observations. Using CO measurements from 1996 to 2007, both Zellweger et al. (2009) and Angelbratt et al. (2011) find decreasing trends for $\mathrm{CO}$ in Europe. The most comparable measurements to satellite total column $\mathrm{CO}$ measurements are those of Angelbratt et al. (2011) that use partial columns of CO $(0-15 \mathrm{~km})$ derived from ground-based solar FTIR (Fourier Transform InfraRed) stations at four locations in Europe. They find trends with $>2 \sigma$ significance of $-0.45 \% \mathrm{yr}^{-1}$ to $-1.00 \% \mathrm{yr}^{-1}$ for $1996-2006$. Although we cannot compare to this time range, our MOPITT and AIRS trends in Europe are consistent with the direction and magnitude of these previously computed trends, and show a somewhat steeper decline after 2007.

Using surface in-situ measurements, Novelli et al. (2003) reported a decreasing trend in the NH for 1991 to 2001 of $0.92 \pm 0.15 \mathrm{ppb} \mathrm{yr}^{-1}$ (or $-0.8 \% \mathrm{yr}^{-1}$ for average $\mathrm{NH}$ values of $\sim 120 \mathrm{ppb}$ ). Our results are consistent with a continuation of this decreasing trend for the NH. The US Environmental Protection Agency (EPA) reports a national decrease in surface CO of $52 \%$ from 2001 to 2010 (EPA, 2011). This corresponds to $-5.2 \% \mathrm{yr}^{-1}$, which is larger than the MOPITT trend for E. USA, $(-1.4 \pm 0.2) \% \mathrm{yr}^{-1}$, but surface CO, measured at mostly urban sites, would be expected to show larger changes compared to total column $\mathrm{CO}$.

$\mathrm{Li}$ and Liu (2011) report a decreasing trend in surface CO in Beijing for 2000 to 2009 from in-situ measurements collected from 8 urban sites using commercial gas filter correlation analyzers. Using the values shown in Fig. 6 of Li and Liu, (2011), this trend appears to be similar to the US EPA surface CO trends, $\sim-6 \% \mathrm{yr}^{-1}$. Li and Liu (2011) also examined MOPITT V4 CO data over Beijing, which did not show a decreasing trend. As described in Sect. 2.1 and shown in Fig. 1, the uncorrected instrument drift in MOPITT V4 data resulted in an increasing $\mathrm{CO}$ column trend that is large enough to obscure the decreasing trends we observe in this study.

In order to understand these trends and the contributions from anthropogenic emissions, fire emissions and possible changes in atmospheric chemistry, a future study for attribution will be needed. This will require data assimilation 

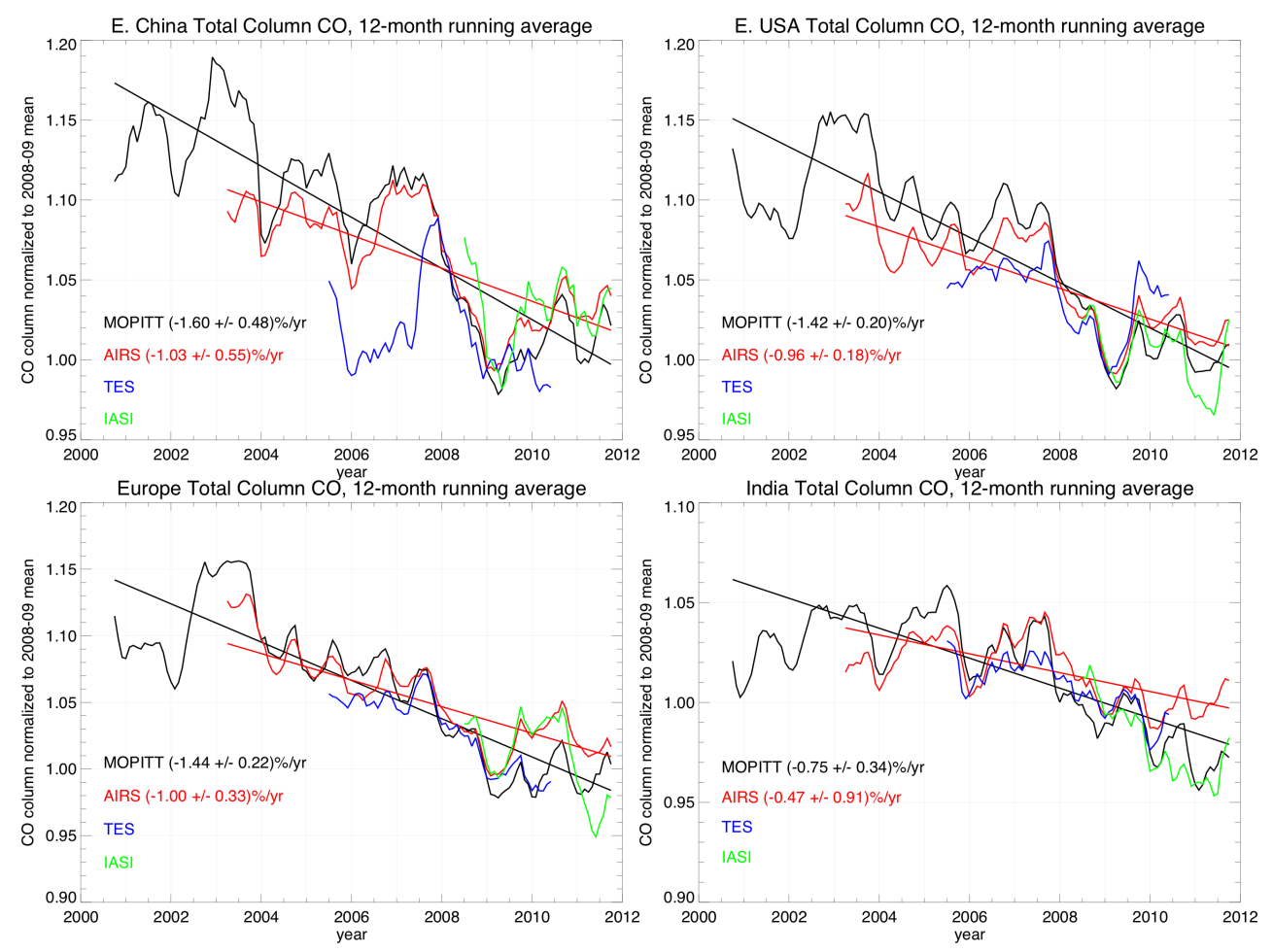

Fig. 8. 12-month running averages for total column CO measurements over E. China. E. USA, Europe and India, normalized by the 08/200807/2009 average CO column for each instrument. See text for description of TES bias due to limited sampling, especially for China during 2005-2007.

and inversion with a model that controls for emissions and $\mathrm{OH}$. Previous studies for trends in $\mathrm{CO}$ emissions have been shown from inversions using MOPITT V4 (Fortems-Cheiney et al., 2011; Hooghiemstra et al., 2012), but this type of study should be updated with MOPITT V5, as well as the AIRS, TES and IASI measurements.

Although this study does not determine how much of the $\mathrm{CO}$ trends reported here are due to changes in anthropogenic emissions, it is interesting to note the reported trends from Granier et al. (2011) from comparing several global and regional emission inventories. They show a very slight decrease in global anthropogenic $\mathrm{CO}$ emissions (around 1\%) from 1990 to 2010, with larger decreases for Europe and USA $\left(\sim 3 \% \mathrm{yr}^{-1}\right)$. However, they show increases for India $\left(\sim 1.5 \% \mathrm{yr}^{-1}\right)$ and China $\left(\sim 3 \% \mathrm{yr}^{-1}\right)$ for 2000 to 2010 . For India, our results show an overall slight decrease, but seem to indicate an increase until about 2007. For China, Granier et al. (2011) include the updated emissions in 2006 from Zhang et al. (2009), but likely did not consider more recent updates to activity data in China such as the inventory used to model CO emissions before and during the 2008 Beijing Olympics (Worden et al., 2012). For Beijing, there were reductions in $\mathrm{CO}$ emissions by 2008 (even without considering the reductions from restrictions during the Olympics) due to such measures as stricter vehicle emission standards, phasing out of residential coal stove use and changes in the industry sector. These changes in the technology mix will have a significant impact on combustion efficiency and therefore $\mathrm{CO}$ emissions. A trend toward improved combustion efficiency from 2005 to 2008 was also found using $\mathrm{CO}_{2}$-CO correlations at a rural site near Beijing by Wang et al. (2010).

We also note that trends in $\mathrm{CO}$ will not necessarily correlate with trends in nitrogen dioxide $\left(\mathrm{NO}_{2}\right)$. A significant increase in $\mathrm{NO}_{2}$ has been observed using satellite data over China in the last decade (e.g., Richter et al., 2005; Zhang et al., 2007). Due to the shorter lifetime of $\mathrm{NO}_{2}$ (hours to days) compared to $\mathrm{CO}$, observations of high $\mathrm{NO}_{2}$ concentrations are more co-located with NOx emission sources, and trends in $\mathrm{NO}_{2}$ abundance are more easily attributed to trends in emissions. For China, NOx emissions are mostly from the power and transportation sectors (Zhang et al., 2009) and have grown significantly since 2000 with the increase in demand for electricity (Zhang et al., 2007). CO emissions, however, have a relatively small contribution $(<2 \%)$ from the power sector (Zhang et al., 2009). Vehicle emission standards and improved combustion efficiency for newer cars will lower CO emissions, but it is not clear whether NOx emissions for the China transportation sector are reduced by the same factor as $\mathrm{CO}$ for these changes. 


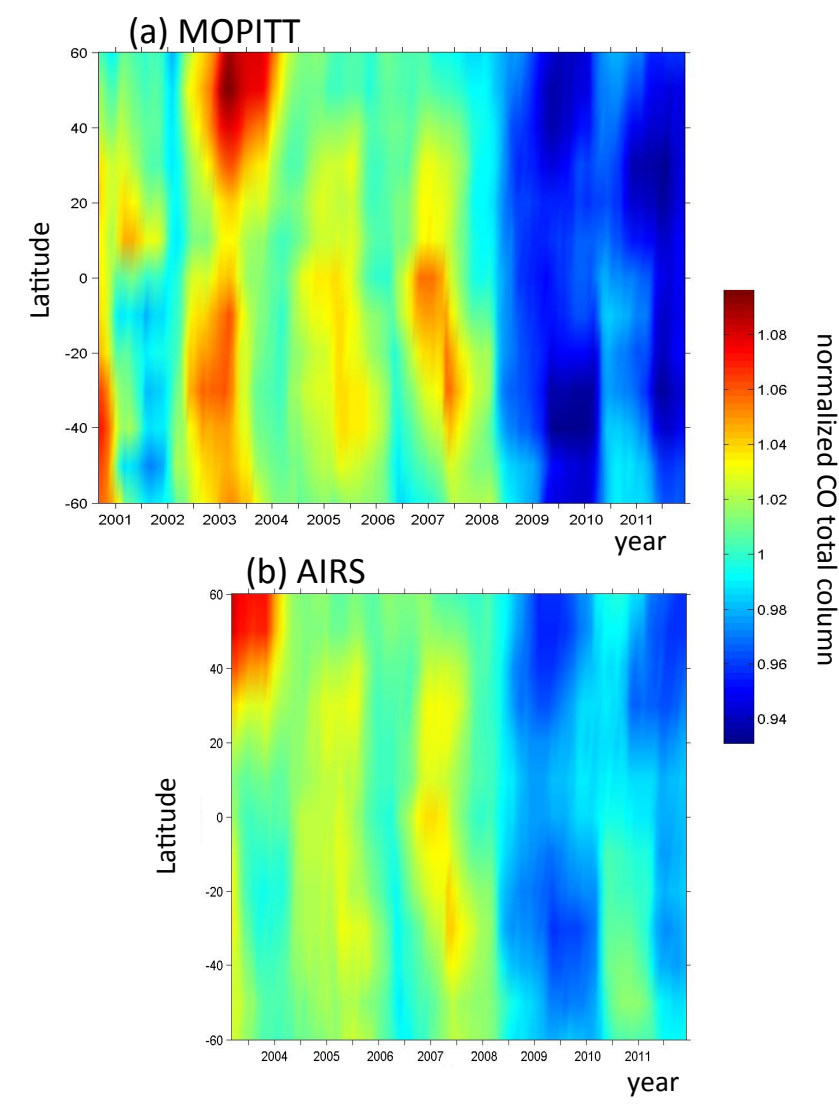

Fig. 9. Time series of normalized CO total column for zonal, 12month running averages. Total $\mathrm{CO}$ columns are normalized to the average column in each $10^{\circ}$ latitudinal band. (a) shows MOPITT data from Sep. 2000 to Nov. 2011. (b) shows AIRS data from April 2003 to November 2011. (First and last 6 months of 12-month running averages are not considered, as described in the text.)

\section{Conclusions}

We have shown that all nadir-viewing TIR satellite measurements of CO total column are consistent with decreasing trends in $\mathrm{CO}$ over the last decade in both Northern and Southern Hemispheres and for specific highly populated regions in the Northern Hemisphere. Hemispherical trends are only significant at the $1 \sigma$ level but regional trends for China, E. USA and Europe are significant to $>2 \sigma$. In particular the decreasing trend in $\mathrm{CO}$ over China of $1.6 \pm 0.5 \% \mathrm{yr}^{-1}$ over 2002-2012 has not been reported before, to our knowledge.

Future studies are needed to test the hypotheses of what is driving the observed hemispherical and regional trends, i.e., changes in emissions (both anthropogenic and biomass burning) or atmospheric chemistry. Although this study does not provide attribution for the decadal changes in $\mathrm{CO}$, we note that changes in fire emissions may explain some of the observed interannual variability, especially in the Southern Hemisphere. We also discussed trends in anthropogenic CO emissions for China that may need to be updated once new

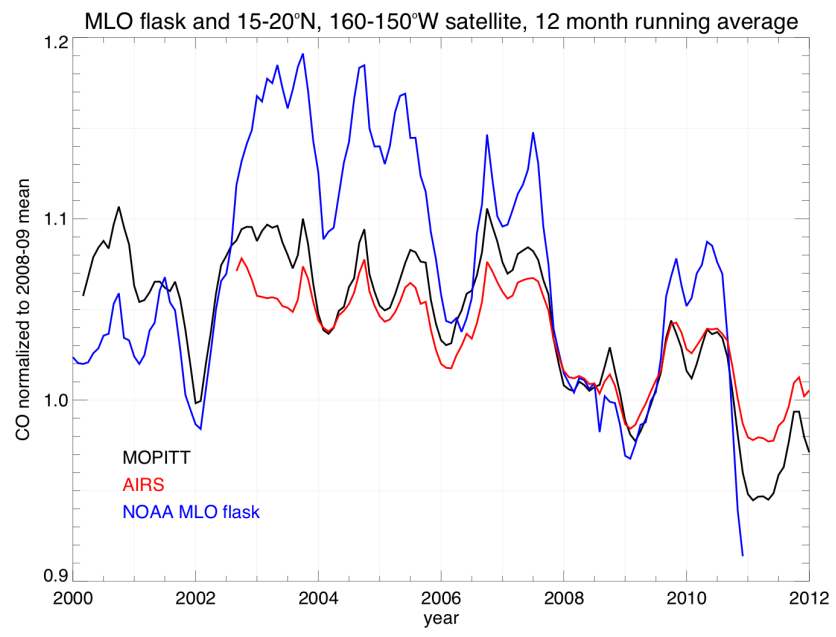

Fig. 10. 12-month running averages for NOAA Mauna Loa (MLO) flask CO vmr and satellite total column CO measurements for 15$20^{\circ} \mathrm{N}, 160-150^{\circ} \mathrm{W}$, (from MOPITT and AIRS) normalized by the 08/2008-07/2009 average values for each measurement type.

inversion results that use recent satellite data versions are available.

These results clearly demonstrate the need for satellite data records that span more than a decade for quantifying trends. Since the US instruments (MOPITT, AIRS and TES) are maturing, it is important to understand the differences in those data records as compared to IASI, which has planned future missions of the same instrument configuration. IASI-B on MetOp-B launched on 17 September 2012 and a third IASI launch is scheduled for 2016. Combined with the existing data records, the IASI instruments will potentially provide $20+$ years of continuous and consistent data for $\mathrm{CO}$ and other trace gas species.

Acknowledgements. The MOPITT, AIRS and TES projects are supported by the National Aeronautics and Space Administration (NASA) Earth Observing System (EOS) Program. The MOPITT team also acknowledges support from the Canadian Space Agency (CSA), the Natural Sciences and Engineering Research Council (NSERC) and Environment Canada, along with the contributions of COMDEV (the prime contractor) and ABB BOMEM. IASI was developed and built under the responsibility of CNES and flies onboard the MetOp satellite as part of the Eumetsat Polar system. The authors acknowledge the Ether French atmospheric database (http://ether.ipsl.jussieu.fr) for distributing the IASI L1C and L2-CO data. AIRS data records and analyses used in this paper were produced with the Giovanni online data system, developed and maintained by the NASA GES DISC. Part of this research was carried out at the Jet Propulsion Laboratory, California Institute of Technology, under a contract with the National Aeronautics and Space Administration. C. Clerbaux and M. George are grateful for the CNES financial support. P. F. Coheur is a Research Associate with F.R.S.-FNRS. The research in Belgium was also funded by BELSPO and ESA (Prodex arrangements). The authors thank 
Louisa Emmons and Mijeong Park at NCAR for their helpful suggestions. The National Center for Atmospheric Research (NCAR) is sponsored by the National Science Foundation.

Edited by: F. Dentener

\section{References}

Ackerman, S. A., Strabala, K. I., Menzel, W. P., Frey, R. A., Moeller, C. C., and Gumley, L. E.: Discriminating clear sky from clouds with MODIS, J. Geophys. Res., 103, 32141-32157, 1998.

Alcorta, L. and Nixson, F.: The Global Financial Crisis and the Developing World: Impact on and Implications for the Manufacturing Sector, United Nations Industrial Development Organization (UNIDO) Working Paper 06/2010, www.unido.org, Vienna, 2011.

Angelbratt, J., Mellqvist, J., Simpson, D., Jonson, J. E., Blumenstock, T., Borsdorff, T., Duchatelet, P., Forster, F., Hase, F., Mahieu, E., De Maziére, M., Notholt, J., Petersen, A. K., Raffalski, U., Servais, C., Sussmann, R., Warneke, T., and Vigouroux, C.: Carbon monoxide $(\mathrm{CO})$ and ethane $\left(\mathrm{C}_{2} \mathrm{H}_{6}\right)$ trends from ground-based solar FTIR measurements at six European stations, comparison and sensitivity analysis with the EMEP model, Atmos. Chem. Phys., 11, 9253-9269, doi:10.5194/acp-11-92532011, 2011.

Arellano, A. F., Kasibhatla, P. S., Giglio, L., van der Werf, G. R., and Randerson, J. T.: Top-down estimates of global CO sources using MOPITT measurements. Geophys. Res. Lett., 31, 1104, doi:10.1029/2003GL018609, 2004.

Aumann, H. H., Chahine, M. T., Gautier, C., Goldberg, M . D., Kalnay, E., McMillin, L., M., Revercomb, H., Rosenkranz, P. W., Smith, W. L., Staelin, D. H., Strow, L. L., and Susskind, J.: AIRS/AMSU/HSB on the Aqua mission: Design, science objectives, data products, and processing systems, IEEE T. Geosci. Remote Sens., 41, 2, 253-264, 2003.

Beer, R.: TES on the Aura mission: Scientific objectives, measurements, and analysis overview, IEEE Trans. Geosci. Remote Sens. 44, 1102-1105, 2006.

Castellanos, P. and Boersma, K. F.: Trends in $\mathrm{NO}_{2}$ and the effects of the economic crisis observed by OMI over Europe, Sci. Reports, 2, 265, doi:10.1038/srep00265, 2012.

Clarisse, L., R'Honi, Y., Coheur, P.-F., Hurtmans, D., and Clerbaux, C.: Thermal infrared nadir observations of 24 atmospheric gases, Geophys. Res. Lett., 38, L10802, doi:10.1029/2011GL047271, 2011.

Clerbaux, C., Edwards, D. P., Deeter, M., Emmons, L., Lamarque, J.-F., Tie, X. X., Massie, S. T., and Gille, J.: Carbon monoxide pollution from cities and urban areas observed by the Terra/MOPITT mission, Geophys. Res. Lett., 35, 3817, doi:10.1029/2007GL032300, 2008a.

Clerbaux, C., George, M., Turquety, S., Walker, K. A., Barret, B., Bernath, P., Boone, C., Borsdorff, T., Cammas, J. P., Catoire, V., Coffey, M., Coheur, P.-F., Deeter, M., De Mazière, M., Drummond, J., Duchatelet, P., Dupuy, E., de Zafra, R., Eddounia, F., Edwards, D. P., Emmons, L., Funke, B., Gille, J., Griffith, D. W. T., Hannigan, J., Hase, F., Höpfner, M., Jones, N., Kagawa, A., Kasai, Y., Kramer, I., Le Flochmoën, E., Livesey, N. J., López-Puertas, M., Luo, M., Mahieu, E., Murtagh, D., Nédélec, P., Pazmino, A., Pumphrey, H., Ricaud, P.,
Rinsland, C. P., Robert, C., Schneider, M., Senten, C., Stiller, G., Strandberg, A., Strong, K., Sussmann, R., Thouret, V., Urban, J., and Wiacek, A.: CO measurements from the ACE-FTS satellite instrument: data analysis and validation using ground-based, airborne and spaceborne observations, Atmos. Chem. Phys., 8, 2569-2594, doi:10.5194/acp-8-2569-2008, 2008b.

Clerbaux, C., Boynard, A., Clarisse, L., George, M., Hadji-Lazaro, J., Herbin, H., Hurtmans, D., Pommier, M., Razavi, A., Turquety, S., Wespes, C., and Coheur, P.-F.: Monitoring of atmospheric composition using the thermal infrared IASI/MetOp sounder, Atmos. Chem. Phys., 9, 6041-6054, doi:10.5194/acp-9-6041-2009, 2009.

Deeter, M. N., Emmons, L. K., Edwards, D. P., Gille, J. C., and Drummond, J. R.: Vertical resolution and information content of CO profiles retrieved by MOPITT. Geophys. Res. Lett., 31, 15112, doi:10.1029/2004GL020235, 2004.

Deeter, M. N., Edwards, D. P., Gille, J. C., and Drummond, J. R.: Sensitivity of MOPITT observations to carbon monoxide in the lower troposphere. J. Geophys. Res., 112, 24306, doi:10.1029/2007JD008929, 2007.

Deeter, M. N., Edwards, D. P., Gille, J. C., Emmons, L. K., Francis, G., Ho, S.-P., Mao, D., Masters, D., Worden, H., Drummond, J. R., and Novelli, P.: The MOPITT Version 4 CO Product: Algorithm Enhancements, Validation, and Long-Term Stability, J. Geophys. Res., 115, D07306, doi:10.1029/2009JD013005, 2010.

Deeter, M. N., Worden, H. M., Gille, J. C., Edwards, D. P., Mao, D., and Drummond, J. R.: MOPITT multispectral CO retrievals: Origins and effects of geophysical radiance errors, J. Geophys. Res., 116, D15303, doi:10.1029/2011JD015703, 2011.

Deeter, M. N., Worden, H. M., Edwards, D. P., Gille, J. C., and Andrews, A. E.: Evaluation of MOPITT Retrievals of Lowertropospheric Carbon Monoxide over the United States, J. Geophys. Res., 117, D13306, doi:10.1029/2012JD017553, 2012.

de Laat, A. T. J., Gloudemans, A. M. S., Schrijver, H., van den Broek, M. M. P., Meirink, J. F., Aben, I., and Krol, M.: Quantitative analysis of SCIAMACHY carbon monoxide total column measurements, Geophys. Res. Lett., 33, L07807, doi:10.1029/2005GL025530, 2006.

de Ruyter de Wildt, M., Eskes, H., and Boersma, K. F.: The global economic cycle and satellite-derived $\mathrm{NO}_{2}$ trends over shipping lanes, Geophys. Res. Lett., 39, L01802, doi:10.1029/2011GL049541, 2012.

Drummond, J. R., Zou, J., Nichitiu, F., Kar, J., Deschambaut, R., and Hackett, J.: A review of 9-year performance and operation of the MOPITT instrument, J. Adv. Space Res., 45, 760-774, doi:10.1016/j.asr.2009.11.019, 2010.

Edwards, D., Halvorson, C., and Gille, J.: Radiative transfer modeling for the EOS Terra satellite Measurement of Pollution in the Troposphere (MOPITT) instrument, J. Geophys. Res., 104, 16755-16775, 1999.

Edwards, D. P., Emmons, L. K., Hauglustaine, D. A., Chu, A., Gille, J. C., Kaufman, Y. J., Pétron, G., Yurganov, L. N., Giglio, L., Deeter, M. N., Yudin, V., Ziskin, D. C., Warner, J., Lamarque, J.F., Francis, G. L., Ho, S. P., Mao, D., Chan, J., and Drummond, J. R.: Observations of Carbon Monoxide and Aerosol From the Terra Satellite: Northern Hemisphere Variability, J. Geophys. Res., 109, D24202, doi:10.1029/2004JD0047272004, 2004.

Edwards, D. P., Emmons, L. K., Gille, J. C., Chu, A., Attié, J.-L., Giglio, L., Wood, S. W., Haywood, J., Deeter, M. N., Massie, S. 
T., Ziskin, D. C., and Drummond, J. R.: Satellite-observed pollution from Southern Hemisphere biomass burning, J. Geophys. Res., 111, 14312, doi:10.1029/2005JD006655, 2006.

Emmons, L. K., Edwards, D. P., Deeter, M. N., Gille, J. C., Campos, T., Nédélec, P., Novelli, P., and Sachse, G.: Measurements of Pollution In The Troposphere (MOPITT) validation through 2006, Atmos. Chem. Phys., 9, 1795-1803, doi:10.5194/acp-91795-2009, 2009.

Emmons, L. K., Walters, S., Hess, P. G., Lamarque, J.-F., Pfister, G. G., Fillmore, D., Granier, C., Guenther, A., Kinnison, D., Laepple, T., Orlando, J., Tie, X., Tyndall, G., Wiedinmyer, C., Baughcum, S. L., and Kloster, S.: Description and evaluation of the Model for Ozone and Related chemical Tracers, version 4 (MOZART-4), Geosci. Model Dev., 3, 43-67, doi:10.5194/gmd3-43-2010, 2010.

EPA, Trends in $\mathrm{NO}_{2}, \mathrm{CO}$, and $\mathrm{SO} 2$ Concentrations, available at http://www.epa.gov/airtrends/2011/, (last access 27 November 2012), 2011.

Forster, P., V. Ramaswamy, P. Artaxo, T. Berntsen, R. Betts, D.W. Fahey, J. Haywood, J. Lean, D.C. Lowe, G. Myhre, J. Nganga, R. Prinn, G. Raga, M. Schulz and R. Van Dorland: Changes in Atmospheric Constituents and in Radiative Forcing. In: Climate Change 2007: The Physical Science Basis. Contribution of Working Group I to the Fourth Assessment Report of the Intergovernmental Panel on Climate Change, edited by: Solomon, S., Qin, D., Manning, M., Chen, Z., Marquis, M., Averyt, K. B., Tignor, M., and Miller, H. L., Cambridge University Press, Cambridge, United Kingdom and New York, NY, USA., 2007.

Fortems-Cheiney, A., Chevallier, F., Pison, I., P. Bousquet, S. Szopa, M. N. Deeter, and C. Clerbaux: Ten years of CO emissions as seen from Measurements of Pollution in the Troposphere (MOPITT), J. Geophys. Res., 116, D05304, doi:10.1029/2010JD014416, 2011.

George, M., Clerbaux, C., Hurtmans, D., Turquety, S., Coheur, P.F., Pommier, M., Hadji-Lazaro, J., Edwards, D. P., Worden, H., Luo, M., Rinsland, C., and McMillan, W.: Carbon monoxide distributions from the IASI/METOP mission: evaluation with other space-borne remote sensors, Atmos. Chem. Phys., 9, 8317-8330, doi:10.5194/acp-9-8317-2009, 2009.

Gloudemans, A. M. S., de Laat, A. T. J., Schrijver, H., Aben, I., Meirink, J. F., and van der Werf, G. R.: SCIAMACHY CO over land and oceans: 2003-2007 interannual variability, Atmos. Chem. Phys., 9, 3799-3813, doi:10.5194/acp-9-3799-2009, 2009.

Granier, C., Bessagnet, B., Bond, T., D’Angiola, A., v. d. Gon, H. D., Frost, G. J., Heil, A., Kaiser, J. W., Kinne, S., Klimont, Z., Kloster, S., Lamarque, J.-F., Liousse, C., Masui, T., Meleux, F., Mieville, A., Ohara, T., Raut, J.-C., Riahi, K., Schultz, M. G., Smith, S. J., Thomson, A., v. Aardenne, J., v. d. Werf, G. R., and v. Vuuren, D. P.: Evolution of anthropogenic and biomass burning emissions of air pollutants at global and regional scales during the 1980-2010 period, Clim. Change, 109, 163-190, doi:10.1007/s10584-011-0154-1, 2011.

Ho, S.-P., Edwards, D. P., Gille, J. C., Luo, M., Osterman, G. B., Kulawik, S. S., and Worden, H.: A global comparison of carbon monoxide profiles and column amounts from Tropospheric Emission Spectrometer (TES) and Measurements of Pollution in the Troposphere (MOPITT), J. Geophys. Res., 114, D21307,doi:10.1029/2009JD012242, 2009.
Holloway, T., Levy II, H., and Kasibhatla, P.: Global distribution of carbon monoxide, J. Geophys. Res., 105, 12123-12147, 2000.

Hooghiemstra, P. B., Krol, M. C., Bergamaschi, P., de Laat, A. T. J., van der Werf, G. R., Novelli, P. C., Deeter, M. N., Aben, I., and Röckmann, T.: Comparing optimized $\mathrm{CO}$ emission estimates using MOPITT or NOAA surface network observations, J. Geophys. Res., 117, D06309, doi:10.1029/2011JD017043, 2012.

Hurtmans, D., Coheur, P.-F., Wespes, C., Clarisse, L., Scharf, O., Clerbaux, C., Hadji-Lazaro, J., George, M., and Turquety, S.: FORLI radiative transfer and retrieval code for IASI. J Quant Spectrosc Radiat Transfer, 113, 1391-1408, doi:10.1016/j.jqsrt.2012.02.036, 2012.

Jones, D. B. A., Bowman, K. W., Logan, J. A., Heald, C. L., Liu, J., Luo, M., Worden, J., and Drummond, J.: The zonal structure of tropical $\mathrm{O}_{3}$ and $\mathrm{CO}$ as observed by the Tropospheric Emission Spectrometer in November 2004 - Part 1: Inverse modeling of CO emissions, Atmos. Chem. Phys., 9, 3547-3562, doi:10.5194/acp-9-3547-2009, 2009.

Kerzenmacher, T., Dils, B., Kumps, N., Blumenstock, T., Clerbaux, C., Coheur, P.-F., Demoulin, P., García, O., George, M., Griffith, D. W. T., Hase, F., Hadji-Lazaro, J., Hurtmans, D., Jones, N., Mahieu, E., Notholt, J., Paton-Walsh, C., Raffalski, U., Ridder, T., Schneider, M., Servais, C., and De Maziére, M.: Validation of IASI FORLI carbon monoxide retrievals using FTIR data from NDACC, Atmos. Meas. Tech., 5, 2751-2761, doi:10.5194/amt5-2751-2012, 2012.

Klonecki, A., Pommier, M., Clerbaux, C., Ancellet, G., Cammas, J.-P., Coheur, P.-F., Cozic, A., Diskin, G. S., Hadji-Lazaro, J., Hauglustaine, D. A., Hurtmans, D., Khattatov, B., Lamarque, J.F., Law, K. S., Nedelec, P., Paris, J.-D., Podolske, J. R., Prunet, P., Schlager, H., Szopa, S., and Turquety, S.: Assimilation of IASI satellite CO fields into a global chemistry transport model for validation against aircraft measurements, Atmos. Chem. Phys., 12, 4493-4512, doi:10.5194/acp-12-4493-2012, 2012.

Kopacz, M., Jacob, D. J., Fisher, J. A., Logan, J. A., Zhang, L., Megretskaia, I. A., Yantosca, R. M., Singh, K., Henze, D. K., Burrows, J. P., Buchwitz, M., Khlystova, I., McMillan, W. W., Gille, J. C., Edwards, D. P., Eldering, A., Thouret, V., and Nedelec, P.: Global estimates of CO sources with high resolution by adjoint inversion of multiple satellite datasets (MOPITT, AIRS, SCIAMACHY, TES), Atmos. Chem. Phys., 10, 855-876, doi:10.5194/acp-10-855-2010, 2010.

Li, L. and Liu, Y.: Space-borne and ground observations of the characteristics of CO pollution in Beijing, 2000-2010, Atmos. Environ., 45, 2367, doi:10.1016/j.atmosenv.2011.02.026, 2011.

Livesey, N. J., Filipiak, M. J., Froidevaux, L., Read, W. G., Lambert, A., Santee, M. L., Jiang, J. H., Pumphrey, H. C., Waters, J. W., Cofield, R. E., Cuddy, D. T., Daffer, W. H., Drouin, B. J., Fuller, R. A., Jarnot, R. F., Jiang, Y. B., Knosp, B. W., Li, Q. B., Perun, V. S., Schwartz, M. J., Snyder, W. V., Stek, P. C., Thurstans, R. P., Wagner, P. A., Avery, M., Browell, E. V., Cammas, J.-P., Christensen, L. E., Diskin, G. S., Gao, R.-S., Jost, H.-J., Loewenstein, M., Lopez, J. D., Nédélec, P., Osterman, G. B., Sachse, G. W., and Webster, C. R.: Validation of Aura Microwave Limb Sounder $\mathrm{O}_{3}$ and $\mathrm{CO}$ observations in the upper troposphere and lower stratosphere, J. Geophys. Res., 113, D15S02, doi:10.1029/2007JD008805, 2008.

Luo, M., Rinsland, C. P., Rodgers, C. D., Logan, J. A., Worden, H., Kulawik, S., Eldering, A., Goldman, A., Shephard, M. W., Gun- 
son, M., and Lampel, M.: TES carbon monoxide validation with DACOM aircraft measurements during INTEX-B 2006, J. Geophys. Res., 112, D24S48, doi:10.1029/2007JD008803, 2007a.

Luo, M., Rinsland, C. P., Rodgers, C. D., Logan, J. A., Worden, H., Kulawik, S., Eldering, A., Goldman, A., Shephard, M. W., Gunson, M., and Lampel, M.: Comparison of carbon monoxide measurements by TES and MOPITT: Influence of a priori data and instrument characteristics on nadir atmospheric species retrievals, J. Geophys. Res., 112, D09303, doi:10.1029/2006JD007663, $2007 b$.

Novelli, P. C., Masarie, K. A., and Lang, P. M.: Distributions and recent changes in carbon monoxide in the lower troposphere, $\mathrm{J}$. Geophys. Res., 103, 19015-19033, 1998.

Novelli, P. C., Masarie, K. A., Lang, P. M., Hall, B. D., Myers, R. C., and Elkins, J. W.: Reanalysis of tropospheric CO trends: Effects of the 1997-1998 wildfires, J. Geophys. Res., 108, 4464, doi:10.1029/2002JD003031, 2003.

Novelli, P. C. and Masarie, K. A.: Atmospheric Carbon Monoxide Dry Air Mole Fractions from the NOAA ESRL Carbon Cycle Cooperative Global Air Sampling Network, 1988-2009, Version: 2011-10-14. Path: ftp://ftp.cmdl.noaa.gov/ccg/co/flask/ event/, 2010.

Pommier, M., Law, K. S., Clerbaux, C., Turquety, S., Hurtmans, D., Hadji-Lazaro, J., Coheur, P.-F., Schlager, H., Ancellet, G., Paris, J.-D., Nédélec, P., Diskin, G. S., Podolske, J. R., Holloway, J. S., and Bernath, P.: IASI carbon monoxide validation over the Arctic during POLARCAT spring and summer campaigns, Atmos. Chem. Phys., 10, 10655-10678, doi:10.5194/acp-10-10655-2010, 2010.

Richter, A., Burrows, J. P., Nüß, H., Granier, C., and Niemeier, U.: Increase in tropospheric nitrogen dioxide levels over China observed from space, Nature, 437, 129-132, doi:10.1038/nature04092, 2005.

Russell, A. R., Valin, L. C., and Cohen, R. C.: Trends in OMI $\mathrm{NO}_{2}$ observations over the United States: effects of emission control technology and the economic recession, Atmos. Chem. Phys., 12, 12197-12209, doi:10.5194/acp-12-12197-2012, 2012.

Susskind, J., Barnet, C. D., and Blaisdell, J. M.: Retrieval of atmospheric and surface parameters form AIRS/AMSU/HSB data in the presence of clouds, IEEE T. Geosci. Remote Sens., 41, 390409, 2003.

Tolton, B. T. and Drummond, J. R.: Characterization of the lengthmodulated radiometer, App. Opt., 36, 5409-5419, 1997.

Turquety, S., Hurtmans, D., Hadji-Lazaro, J., Coheur, P.-F., Clerbaux, C., Josset, D., and Tsamalis, C.: Tracking the emission and transport of pollution from wildfires using the IASI CO retrievals: analysis of the summer 2007 Greek fires, Atmos. Chem. Phys., 9, 4897-4913, doi:10.5194/acp-9-4897-2009, 2009.

van der Werf, G. R., Randerson, J. T., Giglio, L., Collatz, G. J., Mu, M., Kasibhatla, P. S., Morton, D. C., DeFries, R. S., Jin, Y., and van Leeuwen, T. T.: Global fire emissions and the contribution of deforestation, savanna, forest, agricultural, and peat fires (19972009), Atmos. Chem. Phys., 10, 11707-11735, doi:10.5194/acp10-11707-2010, 2010.

Wang, Y., Munger, J. W., Xu, S., McElroy, M. B., Hao, J., Nielsen, C. P., and Ma, H.: $\mathrm{CO}_{2}$ and its correlation with $\mathrm{CO}$ at a rural site near Beijing: implications for combustion efficiency in China, Atmos. Chem. Phys., 10, 8881-8897, doi:10.5194/acp10-8881-2010, 2010.
Warner, J. X., Gille, J. C., Edwards, D. P., Ziskin, D. C., Smith, M. W., Bailey, P. L., and Rokke, L.: Cloud detection and clearing for the Earth Observing System Terra satellite Measurements of Pollution in the Troposphere (MOPITT) experiment, Appl. Optics, 40, 1269-1284, 2001.

Warner, J. X., McCourt Comer, M., Barnet, C., McMillan,W. W., Wolf, W., Maddy, E., and Sachse, G.: A Comparison of Satellite Tropospheric Carbon Monoxide Measurements from AIRS and MOPITT During INTEX-NA, J. Geophys. Res., 112, D12S1, doi:10.1029/2006JD007925, 2007.

Warner, J. X., Wei, Z., Strow, L. L., Barnet, C. D., Sparling, L. C., Diskin, G., and Sachse, G.: Improved Agreement of AIRS Tropospheric Carbon Monoxide Products with other EOS Sensors Using Optimal Estimation Retrievals, Atmos. Chem. Phys., 10, 9521-9533, doi:10.5194/acp-10-9521-2010, 2010.

Worden, H. M., Deeter, M. N., Edwards, D. P., Gille, J. C., Drummond, J. R., and Nédélec, P. P.: Observations of near-surface carbon monoxide from space using MOPITT multispectral retrievals, J. Geophys. Res., 115, D18314, doi:10.1029/2010JD014242, 2010.

Worden, H. M., Cheng, Y., Pfister, G., Carmichael, G. R., Zhang, Q., Streets, D. G., Deeter, M., Edwards,D. P., Gille, J. C., and Worden, J. R.: Satellite-based estimates of reduced $\mathrm{CO}$ and $\mathrm{CO}_{2}$ emissions due to traffic restrictions during the 2008 Beijing Olympics, Geophys. Res. Lett., 39, L14802, doi:10.1029/2012GL052395, 2012.

Yurganov, L. N., Duchatelet, P., Dzhola, A. V., Edwards, D. P., Hase, F., Kramer, I., Mahieu, E., Mellqvist, J., Notholt, J., Novelli, P. C., Rockmann, A., Scheel, H. E., Schneider, M., Schulz, A., Strandberg, A., Sussmann, R., Tanimoto, H., Velazco, V., Drummond, J. R., and Gille, J. C.: Increased Northern Hemispheric carbon monoxide burden in the troposphere in 2002 and 2003 detected from the ground and from space, Atmos. Chem. Phys., 5, 563-573, doi:10.5194/acp-5-563-2005, 2005.

Yurganov, L., McMillan, W., Grechko, E., and Dzhola, A.: Analysis of global and regional $\mathrm{CO}$ burdens measured from space between 2000 and 2009 and validated by ground-based solar tracking spectrometers, Atmos. Chem. Phys., 10, 3479-3494, doi:10.5194/acp-10-3479-2010, 2010.

Zellweger, C., Hüglin, C., Klausen, J., Steinbacher, M., Vollmer, M., and Buchmann, B.: Inter-comparison of four different carbon monoxide measurement techniques and evaluation of the long-term carbon monoxide time series of Jungfraujoch, Atmos. Chem. Phys., 9, 3491-3503, doi:10.5194/acp-9-3491-2009, 2009.

Zhang, Q., Streets, D. G., He, K., Wang, Y., Richter, A., Burrows, J. P., Uno, I., Jang, C. J., Chen, D., Yao, Z. and Lei, Y.: NOx emission trends for China, 1995-2004: The view from the ground and the view from space, J. Geophys. Res., 112, D22306, doi:10.1029/2007JD008684, 2007.

Zhang, Q., Streets, D. G., Carmichael, G. R., He, K. B., Huo, H., Kannari, A., Klimont, Z., Park, I. S., Reddy, S., Fu, J. S., Chen, D., Duan, L., Lei, Y., Wang, L. T., and Yao, Z. L.: Asian emissions in 2006 for the NASA INTEX-B mission, Atmos. Chem. Phys., 9, 5131-5153, doi:10.5194/acp-9-5131-2009, 2009. 